\title{
RANCANGAN PENELITIAN MODEL HYBRID DETEKSI COVID-19 MENGGUNAKAN MARINE PREDATORS ALGORITHM (MPA) DAN INTERPOLASI LINIER
}

\author{
${ }^{1}$ Roni J. Simamora ${ }^{\varpi},{ }^{2}$ Paul Saut Marganda L. Tobing, ${ }^{3}$ Akim M. H. Pardede \\ ${ }^{1}$ Program Studi Manajemen Informatika, Universitas Methodist Indonesia, Medan, Indonesia \\ ${ }^{2}$ Program Studi Pendidikan Dokter, Universitas Methodist Indonesia, Medan, Indonesia \\ ${ }^{3}$ Program Studi Sistem Informasi, STMIK Kaputama, Binjai, Indonesia \\ Email: ronimor4@gmail.com
}

DOI: https://doi.org/10.46880/jmika.Vol5No2.pp142-146

\begin{abstract}
The spread of the COVID 19 outbreak that occurred at the end of 2019 started from the city of Wuhan in China, this outbreak continues to spread to all corners of the world, this outbreak has also reached Indonesia, in Indonesia this outbreak has also spread to all corners of the country, this problem is the focus the government's attention because until now the epidemic cannot be stopped. The problem that occurs is very complex because of the difficulty of controlling the spread that occurs so that more and more residents are confirmed positive for COVID 19 but do not show symptoms in the sufferer, this incident is now called People Without Symptoms (OTG). The spread of the virus through OTGs has played a major role in spreading COVID 19 to other residents. The government has carried out COVID 19 tests on residents, but it still cannot be carried out optimally, this problem is faced by the cost, speed, and accuracy of test data that cannot be obtained optimally. This study proposes to build a hybrid algorithm that can speed up the process of analyzing data on residents who are confirmed positive for COVID 19 through the development of Marine-Predators-Algorithm (MPA) and Linear Interpolation that can be implemented to speed up CT-Scan results of patients' lungs and speed up test results to provide confirmed information. positive for COVID-19 in patients.
\end{abstract}

Keyword: Hybrid Model, Marine Predators Algorithm (MPA), Linier Interpolation, Covid-19.

\begin{abstract}
ABSTRAK
Penyebaran Wabah COVID 19 yang terjadi di akhir tahun 2019 diawali dari kota Wuhan di China, wabah ini terus meluas hingga ke semua penjuru dunia, wabah ini juga sampai ke Indonesia, di Indonesia wabah ini juga menyebar ke seluruh pelosok tanah air, masalah ini menjadi fokus perhatian pemerintah karena sampai saat ini juga wabah tidak dapat dihentikan. Masalah yang terjadi sangat kompleks karena sukarnya kontrol penyebaran yang terjadi sehingga semakin banyak penduduk yang terkonfirmasi positif COVID 19 tetapi tidak menunjukkan gejala pada si penderita, kejadian ini sekarang disebut Orang Tanpa Gejala (OTG). Penyebaran virus melalui para OTG inilah yg sangat berperan besar menyebarkan COVID 19 ke penduduk-penduduk lainnya. Pemerintah telah melakukan uji tes COVID 19 kepada penduduk-penduduk, tetapi masih belum bisa dilakukan secara maksimal, permasalahan ini dihadapkan oleh biaya, kecepatan dan keakuratan data tes yang belum bisa didapatkan secara maksimal. Penelitian ini mengusulkan membangun sebuah algoritma hybrid yang dapat mempercepat proses analisa data penduduk terkonfirmasi positif COVID 19 melalui pengembangan Marine-Predators-Algorithm (MPA) dan Interpolasi Linier yang dapat diimplementasi untuk mempercepat hasil CT-Scan paru pasien dan mempercepat hasil uji untuk memberikan informasi terkonfirmasi positif COVID 19 pada pasien.
\end{abstract}

Kata Kunci: Model Hybrid, Marine Predators Algorithm (MPA), Interpolasi Linier, Covid-19.

\section{PENDAHULUAN}

Alat diagnosis tes COVID 19 sangat terbatas, banyak negara hanya menerapkan tes COVID-19 menggunakan Rapid Tes pada Sebagian besar warga negaranya walaupun melaui rapid tes sudah diketahui hasil uji tes tersebut kurang akurat dalam memberikan kesimpulan apakah orang yang diuji tersebut terinveksi codid 19 atau tidak (Zhu et al., 2020). Pada masa pandemik COVID 19 ini juga ditemukan masalah baru mengenai kebutuhan sumberdaya medis untuk melaukan diagnosa COVID 19, masalah pendeteksian apakah apakah orang yang diuji benar-benar terpapar COVID 19 atau tidak yang perlu ditangani secara cepat, dan perlu dipertimbangkan untuk menghasilkan alat 
yang lebih murah dan akurasinya ketepatannya mendekati $100 \%$.

Banyak upaya yang telah dilakukan untuk menemukan metode atau alat yang lebih baik dan cepat untuk mendeteksi pasien yang terinfeksi sebagi deteksi dini konfirmasi COVID 19 (Pardede, Sihombing, et al., 2019), (Pardede, Mawengkang, Zarlis, \& Tulus, 2019),(Pardede, Zarlis, Mawengkang, \& Tulus, 2019),(Pardede, Novriyenni, \& Kadim, 2020),. Deteksi dini dapat dilakukan melaui pengujian darah, air liur dan hasil CT scan paru-paru pasien (Abdel-Basset, Mohamed, Elhoseny, Chakrabortty, \& Ryan, 2020). Diagnosis COVID 19 dapat direpresentasikan sebagai masalah segmentasi gambar untuk mengekstrak fitur utama dari penyakit. Masalah segmentasi ini dapat diselesaikan dengan mengembangkan algoritma yang memiliki kemampuan untuk mengekstrak file daerah serupa yang lebih kecil yang dapat menunjukkan infeksi COVID 19 dari hasil CT Scan paru-paru (Abdel-Basset et al., 2020).

Meskipun ada banyak metodologi yang ada untuk segmentasi citra medis, tidak ada penelitian yang menyajikan hasil penelitiannya mengenai validasi pada citra dengan tingkat ambang batas (threshold) tinggi yang memiliki kemampuan dalam segmentasi citra dengan banyak wilayah serupa. Selanjutnya, algoritma tersebut mungkin bukan pilihan terbaik untuk mencari wilayah homogen yang lebih kecil dalam gambar medis yang mungkin berisi hasil terckonfirmasi positif penyakit COVID 19. Sebagai upaya untuk meningkatkan algoritma untuk segmentasi citra hasil gambar medis CT scan paru penderita COVID 19 diperlukan algoritma meta-heuristik yang kuat, yaitu meningkatkan kemampuan Marine-PredatorsAlgorithm (MPA) dan interpolasi linier untuk mengelompokkan hasil citra.

Kendala yang ditemukan selama pandemik COVID 19 ini adalah lambatnya penangan tes virus corona untuk mengetahui apakah seseorang sedang mengidap COVID 19 atau tidak (Pardede, Novriyenni, Kadim, \& Buaton, 2021), hasil tes dengan diagnostik dengan sampel atau swab terlalu lama, memakan waktu hingga berhari-hari, sedangkan untuk tes antibodi (rapid test) dalam hitungan detik tetapi terbukti hasilnya tidak bisa diandalkan. Masalah ini menjadi pokok pembahasana dalam penelitian ini yang diharapkan dapat memecahkan masalah bagaimana menemukan model hybrid deteksi COVID-19 menggunakan Marine Predators Algorithm (MPA) dan Interpolasi Linier, sehingga deteksi dini hasil tes diagnosa terkonfirmasi positif COVID 19 dapat dilakukan dalam hitungan detik dan terpercaya.
Adapun tujuan dan sasaran khusus dari penelitian ini adalah:

1. Mengembangkan Marine Predators Algorithm (MPA) dan Interpolasi Linier sebagai deteksi dini Covid-19.

2. Algoritma yang dikembangkan dapat membaca file gambar hasil CT Scan paru pasien dan menghasilkan kesimpulan yang akurat dan terpercaya dalam hitungan detik.

\section{TINJAUAN PUSTAKA}

Beberapa teknik untuk menyediakan alat segmentasi gambar yang efektif, seperti segmentasi berbasis wilayah, deteksi berbasis tepi, pengelompokan berbasis pemilihan fitur, dan segmentasi berbasis ambang/threshold telah dilakukan, dan hasil sementara yang terbaik, tercepat, dan yang lebih akurat adalah segmentasi berbasis ambang, sehingga teknik menggunakan ambang batas dua tingkat/dua level adalah teknik yang paling banyak digunakan pada segmentasi gambar (Narayanan, Hardie, Kebede, \& Sprague, 2019). Dalam thresholding dua level, gambar dipisahkan menjadi dua wilayah: objek dan latar belakang. Meskipun ambang batas dua sangat berguna dalam membagi gambar menjadi hanya dua bagian, banyak aplikasi yang tertarik pada lebih dari dua wilayah (Buaton et al., 2019). Dalam kasus tersebut, teknik threshold (ambang batas) lain yang disebut ambang multi-level telah digunakan untuk mensegmentasi gambar menjadi lebih dari dua wilayah. Meskipun meningkatkan jumlah wilayah yang diekstraksi dari gambar, waktu yang dibutuhkan untuk mengelompokkan gambar meningkat secara eksponensial dengan jumlah wilayah yang diamati.

Teknik ambang batas didasarkan pada dua pendekatan, yaitu Teknik para metrik dan nonparametrik (Dirami, Hammouche, Diaf, \& Siarry, 2013). Dalam pendekatan parametrik, beberapa parameter untuk setiap kelas pada citra perlu dikompilasi menggunakan fungsi densitas probabilitas, namun, dalam pendekatan non parametrik, teknik mencari nilai ambang optimal berdasarkan pada memaksimalkan fungsi yang sesuai (seperti entropi Kapur), entropi fuzzy, dan fungsi Otsu tanpa perlu menghitung parameter di awalnya (Kumar, Gupta, \& Bajaj, 2012).

Karena waktu pemrosesan meningkat secara eksponensial dengan meningkatnya jumlah ambang batas, teknik tradisional akan membutuhkan banyak waktu untuk mencari ambang optimal. Akibatnya, algoritma meta-heuristik telah digunakan sebagai teknik meta-heuristik stokastik yang sangat baik untuk 
mengatasi masalah waktu pemrosesan dan akurasi yang tinggi (Abdel-Basset, Manogaran, El-Shahat, \& Mirjalili, 2018), (Sayed, Hassanien, \& Azar, 2019).

Batas dan ambang potensial yang berisi nilai ambang optimal dengan menggunakan ukuran validitas cluster, dan kemudian menggunakan Genetic Algorithm (GA) untuk mencari ambang optimal dari batas yang ditemukan. GA juga telah diusulkan untuk segmentasi gambar berdasarkan crossover biner simulasi untuk memaksimalkan entropi Kapur untuk citra medis (Manikandan, Ramar, Willjuice Iruthayarajan, \& Srinivasagan, 2014). Di antara algoritma swarm, Particle Swarm Optimization (PSO) telah diusulkan untuk segmentasi citra, di samping meningkatkan kinerjanya dengan pembelajaran kooperatif dan komprehensif untuk menghadapi kutukan dimensionalitas dan untuk mengurangi konvergensi prematur dari masing-masing swarm (Shree, Revanth, Raja, \& Rajinikanth, 2018). PSO yang dimodifikasi juga telah dikembangkan untuk meningkatkan kinerjanya untuk menyelesaikan masalah menggunakan inersia adaptif dan populasi adaptif (Liu, Mu, Kou, \& Liu, 2015), PSO Darwinian orde-fraksional untuk memecahkan masalah ambang batas level-n berdasarkan fungsi Otsu untuk memaksimalkan varian-varian antar kelas (Ghamisi, Couceiro, Martins, \& Benediktsson, 2014).

MPA mensimulasikan mekanisme pencarian makanan yang optimal bagi Marine Predator (predator laut) untuk menemukan mangsa: predator menggunakan strategi Lévy ketika konsentrasi mangsa rendah dan pergerakan Brown ketika mangsa banyak (Faramarzi, Heidarinejad, Mirjalili, \& Gandomi, 2020). Rasio kecepatan $\mathrm{v}$ dari mangsa ke predator mewakili tradeoff antara strategi Lévy dan Brown, yaitu :

1. Pada kecepatan rendah, $v<0,1$, strategi terbaik untuk predator adalah mengikuti jejak Lévy terlepas dari apakah mangsanya bergerak ke arah Brown atau Lévy.

2. Pada kecepatan satuan, $v=1$, pemangsa harus bergerak di Brow jika mangsa bergerak mengikuti kecepatan Lévy.

3. Akhirnya, pada kecepatan tinggi, $v>10$, strategi terbaik untuk predator adalah tetap tidak bergerak, terlepas dari apakah mangsa bergerak ke arah Brown atau Lévy. Model matematis MPA adalah sebagai berikut:

$\vec{X}=\vec{X} \min +\operatorname{rand}(0,1) * \vec{X} \max -\vec{X} \max$
Dimana rand $(0,1)$ adalah bilangan acak dalam rentang [0, 1], dan $\vec{X} \max$ dan $\vec{X} \max$ adalah batas bawah dan batas atas untuk ruang pencarian di setiap dimensi pada masalah optimalisasi.

Setelah melakukan inisialisasi mangsa, kemudian dihitung fitness masing-masing predator, dan predator yang memiliki nilai fitness terbaik ditetapkan menjadi top predator. Berdasarkan survival of the fittest, top predator adalah yang terbaik dalam mencari makan, sehingga digunakan untuk menyusun matriks yang disebut Elite.

\section{METODE PENELITIAN}

Diagram alir penelitian atau metode yang dikembangkan sebagai model yang diajukan pada penelitian ini menjadi Model Hybrid Deteksi COVID19 Menggunakan Marine Predators Algorithm (MPA) dan Interpolasi Linier ini pertama mempelajari teori dan algoritma konsep Marine Predators Algorithm dan Interpolaso Linier yang digunakan serta selanjutnya dilakukan Analisa algoritma pada Teknik ambang (threshold) batas citra dikategorikan sebagai ambang (threshold) batas dua tingkat atau bertingkat. Dalam pekerjaan ini, nilai ambang optimal diperoleh dengan menggunakan metode multilevel populer, yaitu entropi Kapur, yang menentukan nilai ambang optimal berdasarkan entropi daerah tersegmentasi.

Proses Pengulangan Optimasi MPA berdasarkan survival of the fittest, predator teratas adalah yang terbaik dalam mencari makan, jadi pada tahap ini dilakukan penyusunan matriks yang disebut Elite. Pada loop MPA utama, proses optimasi dibagi menjadi tiga tahap berdasarkan rasio kecepatan.

Berikutnya dilakukan Tahap Eksplorasi secara bertahap diubah menjadi eksploitasi, dan pada tahap ini akan didapatkan model matematika dari tahap eksplorasi. Dan untuk mendapatkan hasil yang optimal dilakukan pengujian model algoritma dan simulas model serta validasi model dilakukan untuk mengetahui apakah model tersebut sudah berjalan dengan baik sesuai dengan yang diinginkan. Adapun tahapan penelitian tersebut dijelaskan pada blok diagram alir penelitian pada gambar 1 dibawah ini : 


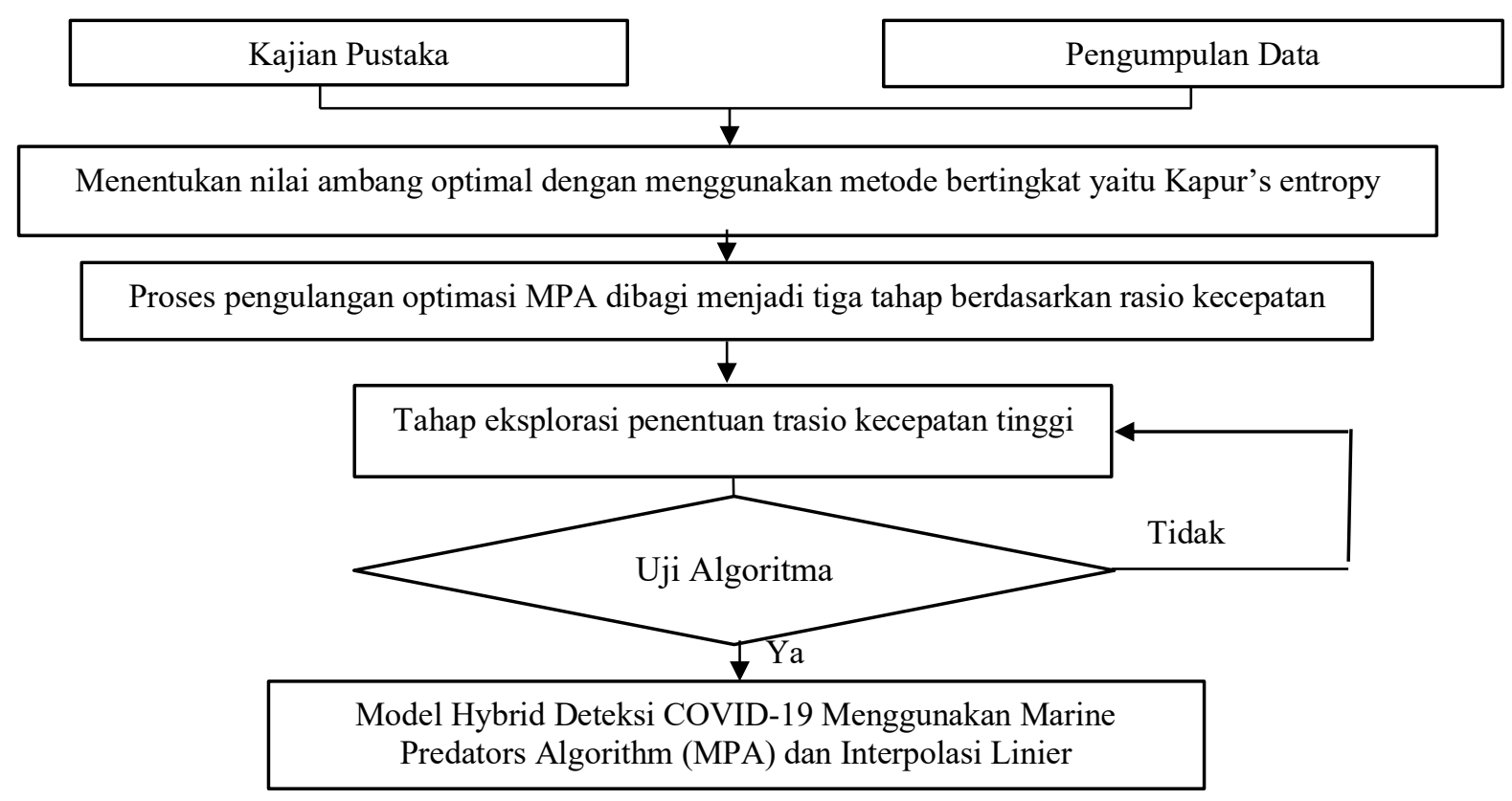

Gambar 3.1 Diagram Alir Penelitian

\section{ANALISA DAN PEMBAHASAN}

Metode Marine Predator Algorithm (MPA) digunakan dalam usulan penelitian ini untuk mendapatkan hasil yang optimal yang didasarkan pada strategi mencari makan yang berbeda di antara predator laut dan kebijakan tingkat perjumpaan yang optimal dalam interaksi biologis. Gerakan Levy dan Brown adalah dua jenis strategi yang dipilih oleh predator laut untuk mencari makan yang optimal, yang diamana jenis pergerakan dan kecepatan mangsa kebijakan pergerakan yang optimal untuk pemangsa (Lévy atau Brownian) dilakukan dengan cara memaksimalkan tingkat pertemuannya dengan mangsa. Dari sudut pandang pergerakan dan di MPA, masa hidup predator terhadap mangsa dibagi menjadi tiga fase yaitu : saat predator bergerak lebih cepat dari mangsa, saat mangsa bergerak lebih cepat dari predator, dan ketika keduanya bergerak dengan kecepatan yang hampir sama. Di setiap fase, kebijakan pergerakan optimal dikaitkan dengan predator untuk menentukan ukuran langkah yang diambil untuk mencapai mangsa. Meniru aturan dan perilaku strategi mencari makan predator laut untuk kemungkinan menghadirkan metaheuristik yang terinspirasi oleh alam nyata yang model matematisnya sedekat dengan model alaminya digunakan sebagai rancangan MPA.

\section{KESIMPULAN}

Penelitian ini membuktikan analisis konvergensi MPA secara eksperimental dan analitis. Analisis konvergensi eksperimental menggunakan metrik kualitatif, termasuk keragaman dan lintasan, sedangkan analisis konvergensi analitik menyatakan bahwa MPA secara analitis konvergen ke titik stabil. Kesederhanaan, kemudahan aplikasi serta hasil yang efektif dan efisien dapat menonjolkan MPA sebagai algoritme optimasi alternatif dari metode klasik. Pemecahan masalah optimasi lain dalam disiplin ilmu yang berbeda dianjurkan untuk evaluasi MPA lebih lanjut. Karena MPA adalah algoritma berbasis kecepatan yang mengembangkan versi biner dan multitujuan MPA akan menjadi kontribusi yang berharga.

Model Hybrid Deteksi COVID-19 Menggunakan Marine Predators Algorithm (MPA) dan Interpolasi Linier dalam penelitian ini dapat membaca file gambar melalui hasil CT Scan paru pasien dan menghasilkan kesimpulan yang akurat dan terpercaya dalam hitungan detik, DAN Dengan adanya penelitian ini diharapkan akan mempercepat diteksi dini COVID 19 pada pasien, sehingga penanganan pasien terpapar COVID 19 dapat dilakukan secara cepat dan tepat sasaran, sehingga penyebaran COVID 19 dapat dihentikan sesegera mungkin.

\section{DISEMINASI}

Artikel ini telah diseminasikan pada Seminar Nasional Inovasi \& Informatika (SNIIf 2021) yang diselenggarakan oleh Fakultas Ilmu Komputer Universitas Methodist Indonesia pada tanggal $23 \mathrm{Juli}$ 2021. 


\section{DAFTAR PUSTAKA}

Abdel-Basset, M., Manogaran, G., El-Shahat, D., \& Mirjalili, S. (2018). A hybrid whale optimization algorithm based on local search strategy for the permutation flow shop scheduling problem. Future Generation Computer Systems. https://doi.org/10.1016/j.future.2018.03.020

Abdel-Basset, M., Mohamed, R., Elhoseny, M., Chakrabortty, R. K., \& Ryan, M. (2020). A Hybrid COVID-19 Detection Model Using an Improved Marine Predators Algorithm and a Ranking-Based Diversity Reduction Strategy. IEEE Access.

https://doi.org/10.1109/ACCESS.2020.2990893

Buaton, R., Mawengkang, H., Zarlis, M., Effendi, S., Manaor Hara Pardede, A., Maulita, Y., ... Novriyenni, N. (2019). Time Series Optimization on Data Mining. Journal of Physics: Conference Series. https://doi.org/10.1088/17426596/1235/1/012014

Dirami, A., Hammouche, K., Diaf, M., \& Siarry, P. (2013). Fast multilevel thresholding for image segmentation through a multiphase level set method. Signal Processing. https://doi.org/10.1016/j.sigpro.2012.07.010

Faramarzi, A., Heidarinejad, M., Mirjalili, S., \& Gandomi, A. H. (2020). Marine Predators Algorithm: A nature-inspired metaheuristic. Expert Systems with Applications. https://doi.org/10.1016/j.eswa.2020.113377

Ghamisi, P., Couceiro, M. S., Martins, F. M. L., \& Benediktsson, J. A. (2014). Multilevel image segmentation based on fractional-order darwinian particle swarm optimization. IEEE Transactions on Geoscience and Remote Sensing. https://doi.org/10.1109/TGRS.2013.2260552

Kumar, T., Gupta, N., \& Bajaj, R. K. (2012). Fuzzy entropy on restricted fuzzy linear regression model with cross validation and applications. Proceedings - 2012 International Conference on Advances in Computing and Communications, ICACC 2012. https://doi.org/10.1109/ICACC.2012.2

Liu, Y., Mu, C., Kou, W., \& Liu, J. (2015). Modified particle swarm optimization-based multilevel thresholding for image segmentation. Soft Computing. https://doi.org/10.1007/s00500-0141345-2

Manikandan, S., Ramar, K., Willjuice Iruthayarajan, M., \& Srinivasagan, K. G. (2014). Multilevel thresholding for segmentation of medical brain images using real coded genetic algorithm. Measurement: Journal of the International Measurement Confederation. https://doi.org/10.1016/j.measurement.2013.09.0 31

Narayanan, B. N., Hardie, R. C., Kebede, T. M., \&
Sprague, M. J. (2019). Optimized feature selection-based clustering approach for computer-aided detection of lung nodules in different modalities. Pattern Analysis and Applications. https://doi.org/10.1007/s10044017-0653-4

Pardede, A. M. H., Mawengkang, H., Zarlis, M., \& Tulus, T. (2019). Optimization of health care services with limited resources. International Journal on Advanced Science, Engineering and Information Technology, 9(4). https://doi.org/10.18517/ijaseit.9.4.8348

Pardede, A. M. H., Novriyenni, N., \& Kadim, L. A. N. (2020). Emergency patient health service simulation as a supporter of smart health care. IOP Conference Series: Materials Science and Engineering. https://doi.org/10.1088/1757899X/725/1/012084

Pardede, A. M. H., Novriyenni, N., Kadim, L. A. N., \& Buaton, R. (2021). Optimization model in public health services to support smart cities. Journal of Theoretical and Applied Information Technology, 99(3).

Pardede, A. M. H., Sihombing, A., Mawengkang, H., Zarlis, M., Tulus, T., Kadim, L. A. N., ... Khair, H. (2019). Smart Health Model With A Linear Integer Programming Approach. Journal of Physics: Conference Series.

Pardede, A. M. H., Zarlis, M., Mawengkang, H., \& Tulus, T. (2019). Limited resources optimization of health care services with a linear integer programming approach. Journal of Theoretical and Applied Information Technology. https://doi.org/10.31224/osf.io/u945r

Sayed, G. I., Hassanien, A. E., \& Azar, A. T. (2019). Feature selection via a novel chaotic crow search algorithm. Neural Computing and Applications. https://doi.org/10.1007/s00521017-2988-6

Shree, T. D. V., Revanth, K., Raja, N. S. M., \& Rajinikanth, V. (2018). A Hybrid Image Processing Approach to Examine Abnormality in Retinal Optic Disc. Procedia Computer Science. https://doi.org/10.1016/j.procs.2017.12.022

Zhu, Y., Liu, Y. L., Li, Z. P., Kuang, J. Y., Li, X. M., Yang, Y. Y., \& Feng, S. T. (2020). Clinical and CT imaging features of 2019 novel coronavirus disease (COVID-19). The Journal of Infection. https://doi.org/10.1016/j.jinf.2020.02.022 